\title{
Hysteroscopy: an effective tool in post-menopausal bleeding
}

\author{
K. K. Junnare*, G. J. Desai, G. S. Shekhawat
}

Department of Obstetrics and Gynecology, Smt. Kashibai Navle Medical College and General Hospital, Pune, Maharashtra, India

Received: 20 October 2018

Accepted: 13 December 2018

*Correspondence:

Dr. K. K. Junnare,

E-mail: ketaki.junnare@yahoo.com

Copyright: ( ) the author(s), publisher and licensee Medip Academy. This is an open-access article distributed under the terms of the Creative Commons Attribution Non-Commercial License, which permits unrestricted non-commercial use, distribution, and reproduction in any medium, provided the original work is properly cited.

\section{ABSTRACT}

Background: Postmenopausal bleeding is a condition where endometrial carcinoma is to be ruled out. Traditionally, $\mathrm{D}$ and $\mathrm{C}$ is the preferred method for diagnosis in such condition. Other diagnostic modalities like trans vaginal ultrasonography (TVS) and hysteroscopy are being used for diagnosis in the cases of PMB. The objective of this study is to evaluate the efficacy and accuracy of TVS and hysteroscopy in women with postmenopausal bleeding (PMB).

Methods: One hundred postmenopausal women with vaginal bleeding underwent TVS and hysteroscopy. Endometrial tissue was obtained by curettage and sent for histopathology examination. The results of TVS and Hysteroscopy were compared against HP report.

Results: Hysteroscopy was successful in 98 patients. Endometrial histopathology revealed proliferative, secretory and atrophic endometrium in 26, 7 and 23 patients respectively. Polyp was diagnosed in 13 patients. Endometrial hyperplasia was detected in 11 patients and endometrial malignancy in 14 patients. All patients with endometrial hyperplasia and malignancy had ET (endometrial thickness) more than $4 \mathrm{~mm}$, except one patient with endometrial malignancy who had $4 \mathrm{~mm}$ ET. The sensitivity and specificity of TVS for suspecting endometrial pathology at ET $4 \mathrm{~mm}$ were $93 \%$ and $69.6 \%$, respectively. Hysteroscopy had sensitivity of $95.2 \%$, specificity of $92.8 \%$, with diagnostic accuracy of $93.8 \%$.

Conclusions: Hysteroscopy was found to be the more sensitive and specific than Transvaginal sonography for diagnosing endometrial pathologies. Hysteroscopy is safe and effective for detecting endometrial pathologies in patients with PMB.

Keywords: Endometrial malignancy, Hysteroscopy, Postmenopausal bleeding (PMB), Transvaginal ultrasonography (TVS)

\section{INTRODUCTION}

Postmenopausal bleeding (PMB) is defined as bleeding that occurs from the genital tract after one year of amenorrhoea, in a woman who is not receiving hormone replacement therapy (HRT). ${ }^{1}$ Vaginal bleeding in postmenopausal women is an alarming symptom. A classic teaching has labelled postmenopausal bleeding as endometrial cancer until proven otherwise. It is estimated that postmenopausal women with vaginal bleeding have a probability of endometrial carcinoma of approximately $10 \% .^{2}$ Dilatation and curettage (D and $\mathrm{C}$ ) was the only option available in the past for evaluating a case of PMB. However focal lesions may be missed on D and C. With Hysteroscopy, entire uterine cavity can be examined, and biopsies can be taken from suspicious areas. However, the role of hysteroscopy in PMB is not very widely discussed in literature. Authors have evaluated women with PMB with TVS and hysteroscopy; and correlated them with endometrial histopathology. 
The aim of this study is to evaluate the efficacy and accuracy of transvaginal ultrasound and hysteroscopy in women with postmenopausal bleeding; to compare the diagnostic accuracy of transvaginal ultrasound and hysteroscopy and to detect intracavitary abnormalities in women with postmenopausal bleeding.

\section{METHODS}

This was a prospective study conducted in Department of Obstetrics and Gynecology at Smt Kashibai Navle Medical College, Pune for 1 year (1 December 2014-30 November 2015). Number of cases were 100.

\section{Inclusion criteria}

- Postmenopausal women with complaint of per vaginal bleeding.

\section{Exclusion criteria}

- Diagnosed cases of endometrial cancer, cervical cancer

- Patients with vaginitis, cervicitis (patients included after treatment of infections)

- Patients not ready to give consent

- Patients who are not likely to follow up.

All postmenopausal women with PMB were included in the study after taking consent. Demographic data, detailed history of patients were noted. General and systemic examination was done. Bimanual examination was performed to assess the size, position, mobility of the uterus and any adnexal pathology. Transvaginal ultrasonography was done to assess uterus, cervix and adnexa. Endometrial thickness was measured for every case. Hysteroscopy was performed routinely in all patients under local anaesthesia with $4 \mathrm{~mm}, 30$ degree rigid telescope. Uterine cavity and cervical canal were explored with hysteroscope. Curettage was done, and endometrial tissue was sent for histopathological examination.

\section{RESULTS}

100 women with postmenopausal bleeding were enrolled in the study, attending gynaecology OPD. Most of the patients were under 50 yrs of age (45\%).

Table 1: Age-wise distribution of study participants $(\mathbf{n}=\mathbf{1 0 0})$.

\begin{tabular}{|l|l|l|}
\hline Age (years) & No. of patients & Percentage \\
\hline$<50$ & 45 & 45 \\
\hline $51-60$ & 42 & 42 \\
\hline $61-70$ & 10 & 10 \\
\hline$>70$ & 3 & 3 \\
\hline Total & 100 & 100 \\
\hline
\end{tabular}

The mean age 53.1 yrs. The youngest of the study group was $40 \mathrm{yrs}$ and the oldest 80 yrs (Table 1).

Table 2: Distribution of study participants as per parity.

\begin{tabular}{|l|l|l|}
\hline Parity & No. of patients & Percentage \\
\hline Nulligravida & 2 & 2 \\
\hline Para 1 & 6 & 6 \\
\hline Para 2 & 38 & 38 \\
\hline Para 3 & 27 & 27 \\
\hline Para 4 & 15 & 15 \\
\hline Para 5 & 7 & 7 \\
\hline Para 6 & 4 & 4 \\
\hline Para 10 & 1 & 1 \\
\hline Total & 100 & 100 \\
\hline
\end{tabular}

Of the total number of 100 women $38 \%$ were para-2 followed by $27 \%$ para- $3.27 \%$ were multiparous and $6 \%$ were para-1.2\% patients were nulligravida. The highest parity in this study was para 10 (Table 2).

Table 3: Distribution of study participants as per transvaginal sonographic findings.

\begin{tabular}{|l|l|l|}
\hline Endometrial thickness & No. of patients & Percentage \\
\hline$\leq 4 \mathrm{~mm}$ & 32 & 32 \\
\hline$>4 \mathrm{~mm}$ & 68 & 68 \\
\hline Total & 100 & 100 \\
\hline
\end{tabular}

In the present study majority of patients i.e. $68 \%$ had endometrial thickness of more than $4 \mathrm{~mm}$. While, $32 \%$ had endometrial thickness of less than or equal to $4 \mathrm{~mm}$ (Table 3).

Table 4: Distribution of study participants as per hysteroscopy features.

\begin{tabular}{|l|l|l|}
\hline Features & No. of patients & Percentage \\
\hline Normal & 35 & 36 \\
\hline Atrophic & 19 & 19 \\
\hline Hyperplastic & 30 & 30 \\
\hline Endometrial polyp & 13 & 13 \\
\hline Posterior wall growth & 1 & 1 \\
\hline Total & 98 & 100 \\
\hline
\end{tabular}

Hysteroscopy revealed no endometrial abnormality in 35 patients while 19 had atrophic endometrium. Endometrial polyp was seen in 13 patients. 30 patients had features suggestive of hyperplastic endometrium (Table 4). In one patient hysteroscopy was not possible due to cervical stenosis whereas other patient's uterine cavity could not be visualised due to bleeding. On histopathological examination, normal endometrium was found in 56 patients. Out of them, 26 had proliferative phase, 7 had secretory phase and 23 had atrophic endometrium (Table 5). 13 patients had endometrial polyp. Simple endometrial hyperplasia without atypia was seen in 8 women; whereas 2 had complex hyperplasia without 
atypia. One patient had complex endometrial hyperplasia with atypia, and 14 had malignancy (Table 5). In one patient histopathology sample could not be collected since dilatation was not possible due to cervical stenosis.

Table 5: Distribution of study participants as per histopathology findings.

\begin{tabular}{|c|c|c|c|c|c|}
\hline \multirow{3}{*}{$\begin{array}{l}\text { Findings } \\
\text { Normal }\end{array}$} & & & & Patients & Percentage \\
\hline & \multicolumn{3}{|l|}{ Proliferative } & 26 & 26 \\
\hline & \multirow{2}{*}{\multicolumn{3}{|c|}{ Secretory }} & 7 & 7 \\
\hline Atrophic & & & & 23 & 23 \\
\hline \multicolumn{4}{|l|}{ Disordered } & 4 & 4 \\
\hline \multicolumn{4}{|c|}{ Hormonal imbalance } & 1 & 1 \\
\hline \multicolumn{4}{|c|}{ Endometrial polyp } & 13 & 13 \\
\hline \multirow{4}{*}{\multicolumn{2}{|c|}{ Hyperplasia }} & \multirow{2}{*}{ Simple } & Without atypia & 8 & 8 \\
\hline & & & With atypia & 0 & 0 \\
\hline & & \multirow{2}{*}{ Complex } & Without atypia & 2 & 2 \\
\hline & & & With atypia & 1 & 1 \\
\hline \multicolumn{4}{|l|}{ Malignancy } & 14 & 14 \\
\hline \multicolumn{4}{|l|}{ Total } & 99 & 100 \\
\hline
\end{tabular}

When ET was compared with histopathology reports, it was seen that none of the patient with endometrial hyperplasia had endometrial thickness less than $4 \mathrm{~mm}$ (Table 6).

Table 6: Transvaginal endometrial thickness in study population with hyperplastic endometrial abnormality on HPE.

\begin{tabular}{|c|c|c|}
\hline Endometrial abnormality & $\mathrm{ET} \leq 4 \mathrm{~mm}$ & $\mathrm{ET}>4 \mathrm{~mm}$ \\
\hline $\begin{array}{l}\text { Simple endometrial } \\
\text { hyperplasia without atypia }\end{array}$ & - & 8 \\
\hline $\begin{array}{l}\text { Simple endometrial } \\
\text { hyperplasia with atypia }\end{array}$ & - & \\
\hline $\begin{array}{l}\text { Complex endometrial } \\
\text { hyperplasia without atypia }\end{array}$ & - & 2 \\
\hline $\begin{array}{l}\text { Complex endometrial } \\
\text { hyperplasia with atypia }\end{array}$ & - & 1 \\
\hline Total & & 11 \\
\hline
\end{tabular}

Table 7 shows that 14 patients with malignancy were detected. All patients with malignancy had endometrial thickness above $4 \mathrm{~mm}$ except one patient whose endometrial thickness was $4 \mathrm{~mm}$. Most common hysteroscopy feature was hyperplastic endometrium followed by endometrial polyp.

The sensitivity of TVS in the present study for ET $>4 \mathrm{~mm}$ is $93 \%$ and the specificity of TVS for ET $\leq 4 \mathrm{~mm}$ is $69.6 \%$ (Table 8). Positive predictive value of TVS was $70.1 \%$ and the negative predictive value was $92.8 \%$. Diagnostic accuracy of TVS is $79.7 \%$.

In this study, the sensitivity of hysteroscopy was $95.2 \%$ and the specificity was $92.8 \%$ (Table 9). Positive Predictive value of the hysteroscopy was $90.9 \%$ and the negative predictive value was $96.3 \%$. Diagnostic accuracy of Hysteroscopy was $93.8 \%$ (Table 9).

Table 7: Transvaginal sonography and hysteroscopy features in study participants with malignancy.

\begin{tabular}{|c|c|c|c|}
\hline \multirow{2}{*}{ Carcinoma } & \multicolumn{2}{|c|}{ TVS } & \multirow{2}{*}{$\begin{array}{l}\text { Hysteroscopy } \\
\text { features }\end{array}$} \\
\hline & $\leq 4 \mathrm{~mm}$ & $>4 \mathrm{~mm}$ & \\
\hline Adenosarcoma & & + & Hyperplastic \\
\hline Adenocarcinoma & & + & Hyperplastic \\
\hline Adenocarcinoma & & + & Hyperplastic \\
\hline $\begin{array}{l}\text { Clear cell } \\
\text { adenocarcinoma }\end{array}$ & & + & Not possible \\
\hline $\begin{array}{l}\text { Papillary } \\
\text { adenocarcinoma }\end{array}$ & & + & Hyperplastic \\
\hline Adenocarcinoma & + & & $\begin{array}{l}\text { Endometrial } \\
\text { polyp }\end{array}$ \\
\hline $\begin{array}{l}\text { Papillary } \\
\text { adenocarcinoma }\end{array}$ & & + & Hyperplastic \\
\hline $\begin{array}{l}\text { Squamotransitional } \\
\text { cell Ca of } \\
\text { endometrium }\end{array}$ & & + & Hyperplastic \\
\hline $\begin{array}{l}\text { Clear cell } \\
\text { adenocarcinoma }\end{array}$ & & + & Hyperplastic \\
\hline $\begin{array}{l}\text { Villo glandular } \\
\text { variant of } \\
\text { adenocarcinoma }\end{array}$ & & + & Hyperplastic \\
\hline $\begin{array}{l}\text { Cervical villo } \\
\text { glandular } \\
\text { adenocarcinoma }\end{array}$ & & + & Hyperplastic \\
\hline $\begin{array}{l}\text { Squamotransitional } \\
\text { cell carcinoma of } \\
\text { cervix }\end{array}$ & & + & Hyperplastic \\
\hline Adenocarcinoma & & + & Hyperplastic \\
\hline $\begin{array}{l}\text { Clear cell } \\
\text { adenocarcinoma }\end{array}$ & & + & Hyperplastic \\
\hline
\end{tabular}


Table 8: Correlation between endometrial thickness on TVS and endometrial abnormality on HPE.

\begin{tabular}{|c|c|c|c|}
\hline ET & $\begin{array}{l}\text { Endometrial } \\
\text { abnormality } \\
\text { present }\end{array}$ & $\begin{array}{l}\text { Endometrial } \\
\text { abnormality } \\
\text { absent }\end{array}$ & Total \\
\hline$>4 \mathrm{~mm}$ & $40(\mathrm{TP})$ & $17(\mathrm{FP})$ & 57 \\
\hline$\leq 4 \mathrm{~mm}$ & $3(\mathrm{FN})$ & 39 (TN) & 42 \\
\hline Total & 43 & 56 & 99 \\
\hline
\end{tabular}

- $\quad$ Sensitivity $=\mathrm{TP} /(\mathrm{TP}+\mathrm{FN}) * 100=93 \%$

- $\quad$ Specificity $=\mathrm{TN} /(\mathrm{TN}+\mathrm{FP}) * 100=69.6 \%$

- $\quad$ Positive predictive value $=\mathrm{TP} /(\mathrm{TP}+\mathrm{FP}) * 100=70.1 \%$

- $\quad$ Negative predictive value $=\mathrm{TN} /(\mathrm{TN}+\mathrm{FN}) * 100=92.8 \%$

Table 9: Correlation between hysteroscopy features and endometrial abnormality on HPE.

\begin{tabular}{|c|c|c|c|}
\hline Hysteroscopy & $\begin{array}{l}\text { Endometrial } \\
\text { abnormality } \\
\text { present }\end{array}$ & $\begin{array}{l}\text { Endometrial } \\
\text { abnormality } \\
\text { absent }\end{array}$ & Total \\
\hline Abnormal & 40 & 4 & 44 \\
\hline Normal & 2 & 52 & 54 \\
\hline Total & 42 & 56 & 98 \\
\hline
\end{tabular}

- $\quad$ Sensitivity $=\mathrm{TP} /(\mathrm{TP}+\mathrm{FN}) * 100=95.2 \%$

- $\quad$ Specificity $=\mathrm{TN} /(\mathrm{TN}+\mathrm{FP}) * 100=92.8 \%$

- $\quad$ Positive predictive value $=\mathrm{TP} /(\mathrm{TP}+\mathrm{FP}) * 100=90.9 \%$

- $\quad$ Negative predictive value $=\mathrm{TN} /(\mathrm{TN}+\mathrm{FN}) * 100=96.3 \%$

\section{DISCUSSION}

Age of patients with postmenopausal bleeding in the current study ranged between 40 years and 80 years with a mean age of 53.15 years (Table 1). This age is much lower than the mean age 64 year by Kaur $M$ et al and 63.6 year by Dawood NS et al..$^{3,4}$

There is a trend towards investigating intracavitary uterine lesions only with postmenopausal bleeding when the endometrial thickness, as measured by ultrasound is $>4 \mathrm{~mm} .^{5}$ Other authors have recommended systemic collection of biopsies from symptomatic patients regardless of endometrial thickness, because of reports of cancer in patients presenting ultrasound-measured endometrial thickness $\leq 5 \mathrm{~mm}$.

$68 \%$ of the patients in the present study had an endometrial thickness of $>4 \mathrm{~mm}$ (Table 4 ). The sensitivity and specificity of TVS for suspecting endometrial pathology at ET $4 \mathrm{~mm}$ were $93 \%$ and $69.6 \%$, respectively (Table 4). Transvaginal ultrasound has a sensitivity of 93\% for detecting endometrial abnormality in present study. This is similar to two other studies $97 \%$ and $87 \%$ respectively, done by Timmermans A et al and Singh P et al (Table 10). ${ }^{8,9}$ The study conducted by Wong et al had sensitivity of $94 \%$ for cut off endometrial thickness of $4 \mathrm{~mm} .{ }^{10}$ In all the three studies cut off ET was set as $4 \mathrm{~mm}$.
Table 10: Comparing sensitivity and specificity of TVS with other studies.

\begin{tabular}{|c|c|c|c|}
\hline Study & $\mathbf{N}$ & Sensitivity & Specificity \\
\hline Gull B et al ${ }^{13}$ & 339 & $100 \%$ & $60 \%$ \\
\hline Kaur $\mathrm{M}$ et $\mathrm{al}^{3}$ & 112 & $100 \%$ & $73 \%$ \\
\hline Timmermans $\mathrm{A}$ et $\mathrm{al}^{8}$ & 540 & $97 \%$ & $56 \%$ \\
\hline Present study & 100 & $93 \%$ & $69.6 \%$ \\
\hline
\end{tabular}

Taipale et al concluded that the sensitivity of ultrasound to detect malignancy was $100 \%$ and specificity was $44 \%$ if cut off of endometrial thickness was $6 \mathrm{~mm} .{ }^{11}$ Karlsson $\mathrm{B}$ and Granberg $\mathrm{S}$ conducted a multicentric study to conclude that no malignant condition was thinner than $5 \mathrm{~mm}$ and the risk of finding pathologic endometrium at curettage when the endometrium was less or equal to $4 \mathrm{~mm}$ as measured by TVS was $5.5 \%$. In present study, one case of endometrial carcinoma had endometrial thickness of $4 \mathrm{~mm} .{ }^{12}$

Gull B detected endometrial cancer in $18.7 \%$ patients with an endometrial thickness more than or equal to 5mm. ${ }^{13}$ Wong et al, conducted a retrospective cohort study on 4383 women to conclude that transvaginal ultrasound using a less than $3 \mathrm{~mm}$ cut off $97 \%$ sensitivity for detecting endometrial cancer and can potentially avoid the need for endometrial sampling in nearly half of the women presenting with postmenopausal bleeding. ${ }^{10}$ In the present study, out of 14 patients with endometrial carcinoma, 13 patients had ET $>4 \mathrm{~mm}$, whereas one patient with clear cell carcinoma had $\mathrm{ET}=4 \mathrm{~mm}$.

In the present study, Hysteroscopy had sensitivity of $95.2 \%$, specificity of $92.8 \%$, positive predictive value $90.9 \%$ and negative predictive value of $96.3 \%$, with diagnostic accuracy of $93.8 \%$ (Table 9). These statistical analysis results correlate with those of Garuti at al who demonstrated sensitivity of Hysteroscopy as 96.5\%, specificity of $93.6 \%$, and positive predictive value as $93.3 \%$ (Table 11). ${ }^{14}$

Table 11: Comparing sensitivity and specificity of hysteroscopy with other studies.

\begin{tabular}{|c|c|c|c|}
\hline Study & $\begin{array}{l}\text { No. of } \\
\text { patients }\end{array}$ & Sensitivity & Specificity \\
\hline Garuti et al ${ }^{14}$ & 419 & $96.5 \%$ & $93.5 \%$ \\
\hline Sousa $R$ et al ${ }^{15}$ & 319 & $97.7 \%$ & $92 \%$ \\
\hline $\begin{array}{l}\text { Tandulwadkar } \\
\text { et } \mathrm{al}^{16}\end{array}$ & 60 & $97 \%$ & $98.5 \%$ \\
\hline Tinelli et al ${ }^{17}$ & 752 & $98 \%$ & $91 \%$ \\
\hline Present study & 100 & $95.2 \%$ & $92.8 \%$ \\
\hline
\end{tabular}

In study by Sousa $\mathrm{R}$ et al, hysteroscopy findings were normal endometrium in two $(2.9 \%)$, suggestive of atrophy in $22(31.9 \%)$, benign focal abnormality in 34 (49.3\%), suspicious focal abnormality in seven (10.1\%), benign diffuse thickness in one $(1.4 \%)$ and suspicious diffuse thickness in two $(2.9 \%)$. 
Purulent endometritis was found in one case (1.4\%). In this study, endometrial polyp was seen in $13 \%$ which was removed by hysteroscopic polypectomy. ${ }^{15}$

Tandulwadkar et al concluded that the sensitivity of hysteroscopy in diagnosing endometrial hyperplasia and endometrial cancer was $93.75 \%$. She inferred that hysteroscopy is much more sensitive than TVS in the detection of focal endometrial pathologies such as endometrial polyp $97 \%$ and $76.7 \%$, respectively. The incidence of endometrial carcinoma was $13.33 \%$, which is comparable to current study i.e. $14 \% .^{16}$

Tinelli et al, conducted a prospective study in 2008 on 752 postmenopausal women with abnormal uterine bleeding underwent TVS and outpatient hysteroscopy with eye directed biopsy. It was concluded that hysteroscopy gave more accurate diagnostic method for detection of endometrial pathology than TVS. ${ }^{17}$

Limitation of the study: the sample size was restricted to hundred patients. More data could have been generated with a bigger sample size.

\section{CONCLUSION}

Hysteroscopy was found to be the more sensitive (95\% vs $93 \%$ of TVS) and specific (92.8\% vs $70 \%$ of TVS) than transvaginal sonography for diagnosing endometrial pathologies, considering histopathology to be the gold standard for diagnosis. Diagnostic accuracy of hysteroscopy $(93.8 \%)$ is better than Transvaginal sonography $(\mathbf{7 9 . 7 \% )}$ in detecting endometrial pathologies. All patients with postmenopausal bleeding need preliminary evaluation by TVS for ET. Women with ET less than $4 \mathrm{~mm}$ can be followed up conservatively so as to prevent unnecessary surgical intervention. Hysteroscopy helps to detect intracavitary lesions like polyps which are responsible for $\mathrm{PMB}$, which can be missed on TVS. Hysteroscopy can be considered as the simple, safe and effective investigation for the evaluation of the patients with PMB.

\section{ACKNOWLEDGMENTS}

Authors would like to acknowledge the faculty members working in the Department of Obstetrics and Gynaecology, SKN Medical College, for their support and help.

Funding: No funding sources

Conflict of interest: None declared

Ethical approval: The study was approved by the Institutional Ethics Committee

\section{REFERENCES}

1. Brand AH. The woman with postmenopausal bleeding. Aus Fam Physic. 2007;36(3):116.
2. Smith-Bindman R, Kerlikowske K, Feldstein VA, Subak L, Scheidler J, Segal M, et al. Endovaginal ultrasound to exclude endometrial cancer and other endometrial abnormalities. JAMA. 1998;280(17):1510-7.

3. Kaur M, Singh R, Sharma M. Endovaginal sonographic evaluation of postmenopausal uterine bleeding. J Clin Diagn Res. 2010;4(2):2175-82.

4. Dawood NS, Peter K, Ibrar F, Dawood A. Postmenopausal bleeding: causes and risk of genital tract malignancy. J Ayub Med Coll Abbottabad. 2010;22(2):117-20.

5. Birinyi L, Daragó P, Török P, Csiszar P, Major T, Borsos A, et al. Predictive value of hysteroscopic examination in intrauterine abnormalities. Europ $\mathbf{J}$ Obstet Gynecol Reprod Biol. 2004;115(1):75-9.

6. Tabor A, Watt HC, Wald NJ. Endometrial thickness as a test for endometrial cancer in women with postmenopausal bleeding. Obstet Gynecol. 2002;99(4):663-70.

7. Litta P, Merlin F, Saccardi C, Pozzan C, Sacco G, Fracas M, et al. Role of hysteroscopy with endometrial biopsy to rule out endometrial cancer in postmenopausal women with abnormal uterine bleeding. Maturitas. 2005;50(2):117-23.

8. Timmermans A, Opmeer BC, Khan KS, Bachmann LM, Epstein E, Clark TJ, et al. Endometrial thickness measurement for detecting endometrial cancer in women with postmenopausal bleeding: a systematic review and meta-analysis. Obstet Gynaecol. 2010;116:160-7.

9. Singh P, Dwivedi P, Mendiratta S. Correlation of endometrial thickness with the histopathological pattern of endometrium in postmenopausal bleeding. J Obstet Gynecol India. 2016;66(1):42-6.

10. Wong AS-W, Lao TT-H, Cheung CW, Yeung SW, Fan $\mathrm{HL}, \mathrm{Ng}$ PS, et al. Reappraisal of endometrial thickness for the detection of endometrial cancer in postmenopausal bleeding: a retrospective cohort study. BJOG. 2016;123:439-46.

11. Taipale P, Tarjanne H, Heinonen UM. The diagnostic value of transvaginal sonography in the diagnosis of endometrial malignancy in women with peri-and postmenopausal bleeding. Acta Obstet Gynecol Scand. 1994;73(10):819-23.

12. Karlsson B, Granberg S, Wikland M, Ylöstalo P, Torvid K, Marsal K, et al. Transvaginal ultrasonography of the endometrium in women with postmenopausal bleeding-a Nordic multicenter study. Am J Obstet Gynecol. 1995;172(5):1488-94.

13. Gull B, Carlsson S, Karlsson B, Yleostalo P, Milsom I, Granberg S. Transvaginal ultrasonography of the endometrium in women with postmenopausal bleeding: is it always necessary to perform an endometrial biopsy? Am J Obstet Gynaecol. 2000;182:509-15.

14. Garuti G, Sambruni I, Cellani F, Garzia D, Alleva P, Luerti M. Hysteroscopy and transvaginal ultrasonography in postmenopausal women with 
uterine bleeding. Int $\mathbf{J}$ Gynecol Obstet. 1999;65(1):25-33.

15. Sousa R, Silvestre M, Sousa LA, Falcão F, Dias I, Silva $\mathrm{T}$, et al. Transvaginal ultrasonography and hysteroscopy in postmenopausal bleeding a prospective study. Acta Obstet Gynecol Scand. 2001;80(9):856-62.

16. Tandulwadkar S, Deshmukh P, Lodha P, Agarwal B. Hysteroscopy in postmenopausal bleeding. J Gynecol Endosc Surg. 2009;1(2):89-93.
17. Tinelli R, Tinelli FG, Cicinelli E, Malvasi A, Tinelli A. The role of hysteroscopy with eye-directed biopsy in postmenopausal women with uterine bleeding and endometrial atrophy. Menop. 2008;15(4):737-42.

Cite this article as: Junnare KK, Desai GJ, Shekhawat GS. Hysteroscopy: an effective tool in post-menopausal bleeding. Int J Reprod Contracept Obstet Gynecol 2019;8:159-64. 